\title{
Investigating the Effect of Peer Feedback on Students' Writing Skill
}

\author{
Rias Wita Suryani ${ }^{1}$, Yenni Rozimela ${ }^{2}$, and Desvalini Anwar ${ }^{3}$ \\ ${ }^{1}$ Universitas Negeri Padang, Padang and Indonesia, $ه($ (email) riaswitaxxx@gmail.com \\ ${ }^{2}$ Universitas Negeri Padang, Padang and Indonesia, $ه$ (email) yennirozi@gmail.com \\ ${ }^{3}$ Universitas Negeri Padang, Padang and Indonesia $ه$ (email) desvalinianwar@yahoo.com
}

\begin{abstract}
The objective of the study was to investigate the effect of peer feedback on students' writing skill. The study adopted quasi-experimental research design. It involved 70 eleventh grade students in two intact classes at one of the public senior high school in West Sumatera, Indonesia. The students were given different types of treatment: the students from experimental class were given feedback from peers, and those from control class were given feedback from teacher. The study lasted 8 weeks. The data were in the form of quantitative data taken from the writing test to obtain students' writing score. The data analysis technique was processed by using t-test. Findings of the study indicated that the students were given peer feedback had better writing skill than the students were given teacher feedback.
\end{abstract}

Keywords: peer feedback, teacher feedback, writing skill

\section{INTRODUCTION}

Since the advent of the writing process approach in second language pedagogy, revision has been considered as a crucial component for improving students' writing. In term of revision way, it is found that giving feedback is the important part (Spiller, 2009). Hence, giving feedback to students' writing should be done during writing process because of its importance, not just giving score for the final product since most of the teachers just focus on the score of final product without informing the student what parts they are wrong or right. In the other words, feedback is seen more useful to the students than what most of the teachers always do; give correction marks to students' draft (Harmer, 2001). Keh (1990) also points out feedback as fundamental element to writing because it provides suggestions, questions, or comment to produce the final writing product. By using feedback, the students can learn why they make the reader confused by not giving proper idea, unclear organization, and inappropriate word-choices and tenses. In addition, a kind of feedback is not just made as the assessment for students' writing, but also to help and teach the students.

There are two different feedbacks; peer and teacher feedbacks. Both feedback types can be used during writing process to help students revise their writing draft because those seem affecting students' writing significantly in particular aspects of writing. Traditionally, teacher is frequently referred to as the ones who could give feedback to students' writing. Many previous studies related to teacher feedback have mainly focused on the nature of teachers' comments, the resulting revisions and the students' reactions to the comments. The findings of studies on teacher feedback also point to some weak areas of traditional teacher feedback and show that in fact teacher feedback is not as infallible as it is commonly believed by students and teachers alike.

Currently, peer feedback advocated by many researchers has figured prominently in writing process (Shehadeh, 2011; Yong, 2010). It is an essential part of the writing process. It is utilized between the drafting and revising stages, considering the process of writing involves four elements: planning, drafting, editing, and final drafting. By doing peer feedback, students can get the four elements in the writing process. It also helps students to know what the strengths and weaknesses of their writing or what are missing from their writing so that they can revise and improve properly. Through this strategy, students could exchange their writing with their partners in order to check the organization of writing. Bartels (2003) also states that in peer feedback students read others' writing and provide feedback, usually answering specific questions that teacher has provided. So, through this strategy, students can get feedback to evaluate their writing better and it is very useful for students in improving their writing skill.

Various issues concerning peer feedback in the teaching writing of foreign language classes have been examined. For example, a study conducted by $\mathrm{Hu}$ (2005) found that peer feedback gives positive impact to students' writing performance. Lee and Shzh (2010) also found that peer feedback improves the content, organization, and vocabulary of the students' writing. Also, Farrah (2012) claimed that peer feedback offers students an opportunity for social interaction and improvement of their writing skills, critical thinking, confidence, creativity, motivation, and assignments. In addition, through the comments from 
peer in terms of content or critical thinking, surface structure/ grammatical aspects, students can improve their writing performance (Srichanyachon, 2011). However, contrasting results also have been informed related to the effectiveness of peer feedback. For example, a study conducted by Nelson and Murphy (1993), revealed that students consider their peer are unable to give proper feedback than themselves, so they tend to have a doubt of peer feedback, so they do not include peer feedback in their writing. Also, Nelson \& Carson (1998) carried out a research revealed that students much more commonly use teacher feedback in their writing than use peer feedback. Even some students were found to be distrusting their own capability in reading others' students writing (Lockhart \& $\mathrm{Ng}$ in Ting \& Qian, 2010).

Therefore, of these finding, peer feedback in the writing classroom still presents problems to solve. Despite peer feedback yields benefits and drawbacks as alternately reported by researchers, peer feedback has been commonly applied in writing class. Moreover, the studies on peer feedback need more investigation and more researches are still required in different contexts to contribute to understanding of the issues of peer feedback in teaching writing. Thus, the researcher conducted this study to investigate the effect of peer feedback as an alternative strategy in teaching writing. Briefly, the objective of this study was to examine the effectiveness of peer feedback on students' writing skill. Therefore, the research question of this study "How effective is peer feedback on students' writing skill at eleventh grade of SMAN 2 Padang Panjang?"

\section{METHODOLOGY}

A quasi- experimental research was conducted to test peer feedback was effective in teaching writing to the students. It was conducted at the SMA Negeri 2 Padang Panjang, academic year 2018/2019, from March to April 2019. The participants of this study were the eleventh grade students. The samples were selected by using cluster random sampling which total number of samples is about 70 students from two classes. One class consisted of 35 students and was treated as the experimental class (XI IPA $1)$. The second class also consisted of 35 students and was treated as the control class (XI IPA 3). In the experimental class, the students were given peer feedback; in the control class, the students were given teacher feedback. The instrument of this study was a writing test. Students were asked to write an explanation text of about 150-200 words by choosing one of the suggested topics that interested them. Each essay is scored on the basis of how effectively it communicates a whole message for the stated purpose. It is also considered in terms of five characteristics: format and mechanics, content and organization, word/sentence use, and grammar. And to the test the hypotheses as the findings in this study, t-test was conducted. Independent sample t-test was intended to test whether or not teacher and peer feedback were effective in teaching writing skill.

\section{RESULTS AND DISCUSSION}

$\mathbf{H}_{\mathbf{0}}$ : the students who were taught by using peer feedback do not have better writing skill than those who were taught by using teacher feedback

$\mathbf{H}_{\mathrm{a}}$ : the students who were taught by using peer feedback have better writing skill than those who were though by using teacher feedback

Since the data was normal and homogenous, the data could be calculated by using parametric statistic. The data was calculated by using independent sample T-test which the value of tobserved was compared to the value of ttable. If the value of tobserved is higher than ttable, it means that Ha will be accepted. However, if the value of tobserved is lower than ttable, it means that $\mathrm{Ha}$ will be rejected. The statistical analysis of students' writing test in experimental and control class by using independent sample T-test through SPSS program is defined in the table below:

Table 1. The statistical analysis of students' writing test in experimental and control class

\begin{tabular}{|c|c|c|}
\hline \multirow{2}{*}{ Data } & $\begin{array}{c}\text { Peer } \\
\text { Feedback }\end{array}$ & $\begin{array}{c}\text { Teacher } \\
\text { Feedback }\end{array}$ \\
\cline { 2 - 3 } & $\mathbf{N}: 35$ & $\mathbf{N}: 35$ \\
\cline { 2 - 3 } & $\boldsymbol{\mu}: \mathbf{7 5 . 2 9}$ & $\boldsymbol{\mu}: \mathbf{7 1 . 9 1}$ \\
\hline $\mathbf{t}_{\text {observed }}$ & \multicolumn{2}{|c|}{$\mathbf{2 . 0 8 0}$} \\
\hline $\mathbf{t}_{\text {table }}$ & \multicolumn{2}{|c|}{$\mathbf{1 . 6 6 7}$} \\
\hline Conclusion & \multicolumn{2}{|c|}{$\begin{array}{c}\mathbf{t}_{\text {observed }}>\mathbf{t}_{\text {table }} \\
\mathbf{H}_{\mathbf{a}} \text { accepted }\end{array}$} \\
\hline
\end{tabular}

From the statistical analysis of students' writing test in experimental and control class above, it can be concluded that the result of the T-test analysis indicates that with the level of significance 0.05 , the value of $t_{\text {observed }}$ is 2.080 which higher than $t_{\text {table }} 1.667$. It means that $\left(\mathrm{H}_{\mathrm{a}}\right)$ is accepted and $\left(\mathrm{H}_{\mathrm{o}}\right)$ is rejected. Therefore, the students who were taught by using peer feedback had better writing skill than those who were taught by using teacher feedback.

Moreover, it can be stated that the mean students' score that taught by using peer feedback (75.29) is higher than those who are taught by using teacher feedback (71.91). Thus, it can be assumed that peer feedback gives positive effect on students writing skill. This is happened because of it provides useful feedback and students could revise their own writing by reading others' writing as critical readers. Based on the findings, it was found that by using peer feedback which is given to the experimental class, enhance students' writing skill. There are some factors which make peer feedback was better than teacher feedback this research. First, it demanded students work in team. They have responsibility to help their friends to understand the material by giving them feedback. Students must communicate with their friends once they could not understand the feedback. Second, in peer feedback they will have to comprehend their peer's work carefully to give the feedback. At that time, unconsciously, they study by themselves and it also grow their motivation to know more. Third, peer feedback demands students to be active. It also supports the situation in the class. Learning a language cannot be understood only by explanation. They 
should practice it frequently. In most classes, the students who passively learn could not understand the material well. Yet, learning by doing is still become the key to comprehend the material well.

However, even though this strategy focus on students as the center of learning, teacher's explanation is still needed to make them easily understand about what they should assess their peers' writing. The students' participation is effective if the teacher give clear explanation about the students' roles and job description and the procedure in doing peer feedback. Another discovery of this research is following stages of writing is very important as includes feedback in some stages of writing could help the students to understand how to write effectively.

Rolllinson (2005) also mentioned that peer feedback is also one of cooperative learning strategies. By working collaboratively, the students will not only see their work from their perspective but also sees from another perspective through their peer. It can be assumed that peer feedback gives more positive effect in engaging students to share and receive ideas, also receive and offer useful feedback in order to improve writing skill. The finding of this research is also supported by Farrah (2012) found that students seen peer feedback as a meaningful experiences, also it provides chance for social interaction. It also improves students' writing skill. From the discussion above, it can be summarized that it gives positive effect in improving their writing skill. Thus, it is an appropriate strategy in engaging students to enhance their writing skill.

\section{CONCLUSION}

The result of this study unveiled that the students who were taught by using peer feedback had better writing skill than those who were taught by using teacher feedback. This is happened because of it provides useful feedback and students could be a critical readers, revise their own writing by reading others' students writing. Apart from the main result, this study also offers some evidence that peer feedback is not effective in dealing with grammatical accuracy than teacher feedback because of the students' inadequate grammar knowledge. So for grammatical errors, students favored teacher feedback than peer feedback. Some recommendations are directed to English teachers and future researchers. For English teachers, it is recommended that they need to consider applying and implementing the combined strategies in the teaching writing. Also, teacher should be well trained in implementing peer feedback. For further researchers, it is hoped to investigate peer feedback in different moderator variable, text types and sample.

\section{ACKNOWLEDGMENTS}

I would like to acknowledge my indebtedness and render my warmest thanks to Prof. Dra. Yenni Rozimela, M.Ed., Ph.D and Desvalini Anwar, S.S., M.Hum., Ph.D who have given valuable advice, meaningful contribution and guidance in accomplishing this research. It is her pleasure to work under their guidance.

\section{REFERENCES}

[1] Barterls, N. (2003). Written peer responses in L2 writing. English Teaching Forum, pp. 34-38

[2] Farrah, M. (2012). The Impact of Peer Feedback on Improving the Writing Skills among Hebron University Students. An-Najah Univ. J. Res. (Humanities). Vol.26(1) pp.180-210

[3] Hansen, J.G and Liu, J. (2005). Guiding Principle for Effective Peer Responses. ELT Journal, 59, pp. $31-38$

[4] Harmer, J. (2001). The Practice of English Language Teaching. Third Edition. Longman Pearson Education Limited.

[5] $\mathrm{Hu},(2005)$. Using peer feedback with Chinese ESL students writers. Language Teaching Research, 9 (2005), pp. 321-342.

[6] Keh, C. L. (1990). Feedback in the Writing Process: A Model and Methods foe Implementation. ELT Journal, 4, pp. 294-394.

[7] Lee, C and Nancy S. (2010). Written peer feedback by EFL students. Komaba Journal of English Education.

[8] Liu, N. F and Carless, D. (2006). Peer feedback: The learning element of peer assessment. Teaching in Higher Education, 11(3), pp. 279-290.

[9] Liu, J and Hansen, J.G. (2002). Peer response in second language writing classrooms. Ann Arbor, MI: University of Michigan Press.

[10] Lundstorm, K and Baker, W. (2009). To give better than to receive: The benefit of peer review to the reviewer's own writing. Journal of Second Language Writing, 18(1), pp. 30-43. I

[11] Nelson, G and Carson, J. (1998). ESL students' perceptions of effectiveness in peer responses groups. Journal of Second Language Writing, 7(2), pp. 113-131.

[12] Rollinson, P. (2005). Using peer feedback in the ESL writing Class. ELT Journal, 59(1), pp. 23-3-.

[13] Srichanyachon, N. (2011). A comparative study of three revision method in EFL writing. Barcelona Academic European Conference: Thailand

[14] Ting, M. E. I and Qian, Y.U.A.N. (2010). A case study of peer feedback in a Chinese EFL writing classroom. Chinese Journal of Applied Linguistics, 33(4), pp. 87-98.

[15] Tsui, A and Ng, M. (2000). Do secondary L2 writere benefit from peer comments? Journal of Second Language Writing, 9(2), pp. 147-170. 